A C G

publications

Org. Commun. 14:2 (2021) 144-156

organic

communications

\title{
Synthesis, characterization, crystal structure and bioactivities of
}

novel enamine and pyrrole derivatives endowed with

acetylcholinesterase, $\alpha$-glycosidase and human carbonic

anhydrase inhibition effects

\author{
Abel Maharramov ${ }^{(1}$, Malahat Kurbanova ${ }^{(1}$, Parham Taslimi ${ }^{(}$, \\ Yeliz Demir ${ }^{\oplus}{ }^{3}$, Aytan Safarova ${ }^{1}$, Elnur Huseyinov $\oplus^{1}$, \\ Afsun Sujayev $\oplus^{1}$, Saleh H. Alwasel $\oplus^{5}$ and IIlhami Gulcin $\oplus^{6 * *}$ \\ ${ }^{1}$ Baku State University, Organic Chemistry Department, Z. Khalilov 23, Baku, 1148, Azerbaijan \\ ${ }^{2}$ Bartin University, Faculty of Science, Department of Biotechnology, 74100-Bartin, Türkiye \\ ${ }^{3}$ Ardahan University, Nihat Delibalta Göle Vocational High School, Department of Pharmacy \\ Services, 75000-Ardahan, Türkiye \\ ${ }^{4}$ Azerbaijan National Academy of Sciences, Laboratory of Organic chemistry, Institute of Chemistry of \\ Additives, 1029-Baku, Azerbaijan \\ ${ }^{5}$ King Saud University, College of Science, Department of Zoology, Riyadh, Saudi Arabia \\ ${ }^{6}$ Ataturk University, Faculty of Science, Department of Chemistry, 25240-Erzurum, Türkiye
}

(Received April 03, 2021; Revised April 21, 2021; Accepted April 30, 2021)

\begin{abstract}
Presented research work is devoted to the synthesis of new heterocyclic compounds containing the ethyl ester fragment of acetate and glycine and the study of their crystal structure and biological activity. (Z)-Ethyl 2-(3oxo-1,3-diphenylprop-1-enylamino)acetate (1) was first obtained on the base of the reaction of dibenzene methane with glycine ethyl ester hydrochloride in the presence of $Y(O T F) 3$ catalyst in aqueous medium. At the same time, ethyl-3,5-diphenyl-1 $H$-pyrrole-2-carboxylate (2) was synthesized from the interaction of enamine with tert-BuOK in the presence of tert-BuOH/DMFA solvent. The structure of new compounds has been studied by $1 \mathrm{H},{ }^{13} \mathrm{C} \mathrm{NMR}$. In addition, the crystal structure of ethyl-3,5-diphenyl-1H-pyrrole-2-carboxylate (2) is presented. The monoclinic, yellow crystals, with sizes $0.20 \times 0.10 \times 0.10 \mathrm{~mm}^{3}$, one striped: $\mathrm{a}=10.5340(6) \mathrm{E}, \mathrm{b}=7.5101(5) \mathrm{E}, \mathrm{c}=20.2352(15)$ $\AA, \beta=102.131(2)^{\circ}, \mathrm{V}=1565.09(18) \mathrm{E}^{3}$, space group $\mathrm{P} 2_{1} / \mathrm{c}, \mathrm{Z}=4, \mathrm{ds}=1.236 \mathrm{mg} / \mathrm{m}^{3}, \mu=0.080 \mathrm{~mm}^{-1}$ were obtained. The crystalline compound keeps crystallographically independent molecules in the central bicyclic moiety. Compound 2 holds complex three-organic compound system consisting of pyrrole and benzol rings. In this study, the $\mathrm{IC}_{50}$ and $\mathrm{K}_{\mathrm{i}}$ values of the compounds were calculated to compare their inhibition profiles on acetylcholinesterase (AChE), $\alpha$-glycosidase and hCA I, and II isozymes. These compounds demonstrated Ki values in the low micromolar range for studied enzymes. The best inhibitor for hCA I and II isoenzymes and AChE was the (1) with Ki values of 47.21 $\pm 5.06,35.77 \pm 3.53$ and $103.94 \pm 15.36 \mu \mathrm{M}$, respectively. On the other hand, compound 2 showed the best inhibition profile against $\alpha$-glycosidase with $\mathrm{Ki}$ of $63.76 \pm 7.12 \mu \mathrm{M}$.
\end{abstract}

Keywords: Enamine; acetylcholinesterase; pyrrole; carbonic anhydrase; $\alpha$-glycosidase (C2021 ACG Publication. All right reserved.

* Corresponding author: E-Mail: igulcin@atauni.edu.tr, Phone: + 90 4442314375; Fax: + 904422310941. 
Maharramov et al., Org. Commun. (2021) 14:2 144-156

\section{Introduction}

Pyrrole and pyrrole derivatives from nitrogenous heterocycles are biologically active compounds ${ }^{1}$. They can be found in many natural compounds. That's why these compounds are in the interest of researchers. Pyrrole and its derivatives have a special place among the pentagonal heterocyclic compounds. It's known that many important physiologically active natural organic compounds like chlorophyll, hemoglobin, vitamin $\mathrm{B}_{12}$, Crisprine A, Lamellarin D and Lettowainthine contain pyrrole ring. The antibacterial, antidiabetic, antimicrobial and other biological properties of pyrroles make them more popular ${ }^{2}$. In the modern time, the five substituted optically active derivatives of pyrrole is the most widely used drug to lower blood cholesterol ${ }^{3}$. 3,5-Disubstituted-1H-pyrrole-2carboxylate was synthesized in the literature by microwave irradiation of 1,3-disubstituted propene-2on and ethyl nitroacetate in the presence of triethylphosphite $\left(\mathrm{P}(\mathrm{OEt})_{3}\right)$ and diethylamine ${ }^{4}$. Another method is the treatment of ethyl-2-nitro-5-oxo-3,5-diarylpentanoate with triethylphosphite exposed microwave irradiation ${ }^{5}$. Also, it was obtained pyrrole-2-carboxypyrroles by electrocyclic ring closure of chalcones and glycine esters or amides ${ }^{6}$. Although many researchers have synthesized similar pyrroles. We obtained 3.5-dialkyl (phenyl)-pyrrole-2-ethylcarboxylates from the reaction of enamines and glycine ethyl ester hydrochloride in the presence of tert-BuOK/tert-BuOH for the first time.

At the same time, the $\beta$-enamines that we used as another component in this study are important synthetics for a number of active compounds, such as enzymes inhibitors ${ }^{7}$, dopamine auto receptors, agonists, anticonvulsants ${ }^{8}$, and etc. Enamines are of particular importance because they are used as intermediates in the formation of the taxol chain ${ }^{9}$. They are also used in the synthesis of polyunsaturated pyrrole and other heterocycles and various colored pigments ${ }^{10}$. Because of easy nucleophilic and electrophilic attack properties enamines were used in the synthesis of different heterocycles and natural compounds. In addition to the short reaction time, high yield, and simplicity of the process, many researchers have focused on synthesizing enamines in a pure way without toxic catalysts ${ }^{11}$.

Carbonic anhydrases (CAs, E.C.4.2.1.1) present in all organisms over the phylogenetic trees and are encoded by at least eight different genetic families ${ }^{12-15}$. CAs catalyzes an important biological reaction reversible hydration of carbon dioxide $\left(\mathrm{CO}_{2}\right)$ to produce hydronium ions $\left(\mathrm{H}_{3} \mathrm{O}^{+}\right)$and bicarbonate $\left(\mathrm{HCO}_{3}{ }^{-}\right)^{16-18}$. CAs acted in numerous biological processes, starting with $\mathrm{pH}$ regulation and ending with metabolism. Abnormal levels or activities of CA isoenzymes are related to numerous human disorders ${ }^{19-21}$. Hence, it is significant to discover a potent approach that can inhibit the CA isoforms involved in many diseases ${ }^{22,23}$. Pharmacological applications of CA inhibitors (CAIs) have found place in many fields such as acid-base disequilibria, ulcers, glaucoma and neurological disorders. Most of $\alpha$ CA isoforms available in mammals and humans. Recently, highly effective as CAIs like sulfonamides has been used as non-selective inhibitors. Hence, the design and synthesis of new and selective CAIs had a great importance. ${ }^{24-26}$.

Alzheimer's disease (AD) is a multifactorial and highly prevalent neurodegenerative disease, and globally cause of dementia in elder people worldwide ${ }^{27}$. Great interest was gathered due to the increasingly rejuvenation of the crowd attached to the disease ${ }^{28,29}$. Because cholinergic pathways are associated with $\mathrm{AD}$ progression and cholinergic loss has a correlation with the severity of dementia in $\mathrm{AD}$, some of the pharmacotherapies available for this disease contain acetylcholinesterase inhibitors (AChEIs) that used for the symptoms treatment ${ }^{30-32}$. AChEIs are effective and feasible strategies to increase ACh levels in the brain for AD treatment. Also, AChEIs are clinically used to treat glaucoma, myasthenia gravis, neuromuscular disturbance, and AD. Moreover, cholinesterase inhibitors have extensive usage as pesticides, which can generate toxic responses in human and mammals ${ }^{33-35}$.

On the other hand, diabetes mellitus (DM) is one a major global problem for public health and well-known metabolic disorder, which is characterized as an unusual postprandial enhance of blood glucose level. The control of postprandial hyperglycemia is known one of significant therapy method of $\mathrm{DM}^{36-38} . \alpha$-Glycosidase hydrolyses the glycosidic bond between two or more carbohydrates. It exists in intestinal chorionic epithelium, which is accountable for the depreciation of carbohydrates. A lot of researches on development of effective hypoglycemic methods have provided discoveries of molecular therapy targets including $\alpha$-glycosidase inhibition. $\alpha$-Glycosidase inhibitors (AGIs) fall under the third class of oral hypoglycemic factors. Recently a growing interest has been observed in design and synthesis of bioactive compounds due to their potential and powerful antidiabetic potencies ${ }^{40-42}$. 
Synthesis, characterization and bioactivity of novel enamine and pyrrole derivatives

The aim of the present study was to find out the inhibition properties of a novel enamine and pyrrole derivatives against hCA isoenzymes, acetylcholinesterase and $\alpha$-glycosidase enzymes that linked to some global diseases including diabetes mellitus, glaucoma and Alzheimer's disease.

\section{Experimental}

\subsection{Measurements}

${ }^{1} \mathrm{H}$ NMR and ${ }^{13} \mathrm{C}$ NMR spectra were performed on a 400-spectrophotometer using in DMSO$d_{6}$. Chemical shifts values are recorded in ppm taking tetramethyl silane (TMS) as the internal standard and $\mathbf{J}$ values are given in hertz. The signal types are indicated by the following letters: $\mathrm{s}=$ singlet, $\mathrm{m}=$ multiplets, $\mathrm{t}=$ triplet and $\mathrm{d}=$ doublet. Also, $\mathrm{X}$-ray structure analysis was used for confirmation of structure of compound 2. NMR experiments have been performed on a Bruker FT NMR spectrometer AVANCE $300\left(300 \mathrm{MHz}\right.$ for ${ }^{1} \mathrm{H}$ and $75 \mathrm{MHz}$ for ${ }^{13} \mathrm{C}$ ) with BVT 3200 variable-temperature unit in 5 mm sample tubes using Bruker Standard software (Topspin 3.1). The ${ }^{1} \mathrm{H}$ and ${ }^{13} \mathrm{C}$ chemical shifts were referenced to internal TMS. The NMR grade DMSO- $d_{6}\left(99.7 \%\right.$, including $\left.0.3 \% \mathrm{H}_{2} \mathrm{O}\right)$ was used for both synthesized compounds.

Flash column chromatography was realized using by glass columns with flash grade silica gel (70-230 mesh). Reactions tracking were watched by thin layer chromatography (TCL) and visualized by UV light. All organic extracts were dehydrated over oven-dried $\mathrm{MgSO}_{4}$. The structure of the synthesized compounds was confirmed by the diffraction spectrum "Bruker APEX II CCD" (T = 296 $\mathrm{K}, \lambda \mathrm{MoK} \alpha$-radiation, graphite monochromator, $\varphi$ - and $\omega$-scanning, $2 \theta \max =46^{\circ}$ ). The additional information about NMR and X-ray structure analysis of the investigated compounds are provided as Supporting Information. Dibenzoylmethane (98\% Sigma Aldrich), glycine ethyl ester hidrochloride (ethyl glycinate hydrochloride) ( $\geq 98.5 \%$ Sigma Aldrich), yttrium(III) trifluoromethanesulfonate (trifluoromethanesulfonic acid yttrium(III) salt, yttrium triflate, 98\% Sigma Aldrich), potassium tertbutoxide (potassium tert-butylate, potassium t-butoxide ( $\geq 98 \%$ Sigma Aldrich).

\subsection{Crystallography}

Suitable crystals of (2) were selected for data collection, which was performed on a D8-QUEST diffractometer equipped with graphite-monochromatic Mo Ka radiation. The structures were solved by direct methods using SHELXS-9743. They refined by full-matrix least-squares methods on F2 using SHELXL-97 from within the WINGX ${ }^{44}$. All non-hydrogen atoms were refined with anisotropic parameters. Molecular diagrams were created using MERCURY ${ }^{45}$. Also, supramolecular analyses were performed and the diagrams were prepared with the aid of PLATON ${ }^{46}$. Detailed information of crystal structure determinations and data collection are summarized in Table S1 (see supporting information file).

\subsection{Synthesis}

\subsection{1. (Z)-Ethyl 2-(3-oxo-1,3-diphenylprop-1-enylamino)acetate (1)}

The $1 \mathrm{~mL}$ of dibenzoylmethane was mixed with $10 \mathrm{mmol}$ glycine ethyl ester hydrochloride in aqueous medium in the presence of $5 \mathrm{~mol} \% \quad Y(O T F) 3$ for 6 hours at $25^{\circ} \mathrm{C}$. The course of the reaction was monitored by TLC. Then mixture was twice extracted with $10 \mathrm{~mL}$ diethyl ether. The reaction products were separated by column chromatography. Eluent $\mathrm{n}$-hexane: ethyl acetate 10:1. Melting point: 128-130 ${ }^{\circ} \mathrm{C} .{ }^{1} \mathrm{H}$ NMR $(300 \mathrm{MHz}, \mathrm{DMSO}-\mathrm{d} 6), \delta[\mathrm{ppm}]: 1.07\left(3 \mathrm{H}, \mathrm{t}, \mathrm{CH}_{3}\right), 4.02\left(\mathrm{k}, 2 \mathrm{H}, \mathrm{CH}_{2} \mathrm{O}\right), 4.84(\mathrm{~d}$, $\left.2 \mathrm{H}, \mathrm{CH}_{2}\right), 5.83(\mathrm{~s}, 1 \mathrm{H}, \mathrm{CH}), 7.22-8.37(\mathrm{~m}, 10 \mathrm{H}, 2 \mathrm{Ar}-\mathrm{H}), 11.38(\mathrm{t}, 1 \mathrm{H}, \mathrm{NH}) .{ }^{13} \mathrm{C}$ NMR (DMSO-d $\left.d_{6}\right), \delta$ [ppm]: $14.28 \mathrm{CH}_{3}, 46.33 \mathrm{CH}_{2} \mathrm{~N}, 61.35 \mathrm{CH}_{2} \mathrm{O}, 93.60 \mathrm{CH}=, 128.76 \mathrm{CH}_{\mathrm{ar}}, 128.91 \mathrm{CH}_{\mathrm{ar}}, 129.17 \mathrm{CH}_{\mathrm{ar}}$, $131.44 \mathrm{CH}_{\mathrm{ar}}, 133.28 \mathrm{CH}_{\mathrm{ar}}, 135.07 \mathrm{CH}_{\mathrm{ar}}, 130.17 \mathrm{C}_{\mathrm{ar}}, 134.43 \mathrm{C}_{\mathrm{ar}}, 166.13 \mathrm{~N}-\mathrm{C}=, 169.97 \mathrm{COO}, 196.03 \mathrm{CO}$.

\subsubsection{Ethyl 3,5-diphenyl-1H-pyrrole-2-carboxylate (2)}

The $0.85 \mathrm{~g}$ enamine $\left(\mathrm{C}_{6} \mathrm{H}_{5} \mathrm{COCH}=\mathrm{CCH}_{3} \mathrm{NHCO}_{2} \mathrm{C}_{2} \mathrm{H}_{5}\right)$ and $0.67 \mathrm{~g}$ of tert-BuOK were added to a round bottom flask in $5 \mathrm{~mL}$ of tert-BuOH and $10 \mathrm{~mL}$ DMFA and was mixed for $4-5$ hours at $80^{\circ} \mathrm{C}$. 
Maharramov et al., Org. Commun. (2021) 14:2 144-156

Then, the mixture was allowed and extracted twice with $30 \mathrm{~mL}$ diethyl ether and washed with water. After expulsion, the mixture was separated by column chromatography. Eluent n-hexane: ethyl acetate (10:1). Yellow crystals were obtained. Melting point: $140-144^{\circ} \mathrm{C}$, yield $45-50 \%$. ${ }^{1} \mathrm{H}$ NMR $(300 \mathrm{MHz}$, DMSO- $\left.d_{6}\right), \delta[\mathrm{ppm}]: 1.18\left(\mathrm{t}, 3 \mathrm{H}, \mathrm{CH}_{3}\right) ; 4.17\left(\mathrm{k}, 2 \mathrm{H}, \mathrm{CH}_{2} \mathrm{O}\right), 6.74(\mathrm{~s}, 1 \mathrm{H}, \mathrm{CH}=) ; 7.30-7.90(\mathrm{~m}, 10 \mathrm{H}$, 10Ar-H), $11.94(\mathrm{~s}, 1 \mathrm{H}, \mathrm{NH}) .{ }^{13} \mathrm{CNMR}$ (DMSO- $\left.d_{6}\right), \delta[\mathrm{ppm}]: 14.54 \mathrm{CH}_{3}, 60.07 \mathrm{CH}_{2} \mathrm{O}, 110 \mathrm{CH}_{\mathrm{pyr}}, 118.71$ $\mathrm{C}_{\mathrm{pyr}}-\mathrm{CO}, 125.83 \mathrm{CH}_{\mathrm{ar}}, 127.00 \mathrm{CH}_{\mathrm{ar}}, 127.94 \mathrm{CH}_{\mathrm{ar}}, 130.17 \mathrm{CH}_{\mathrm{ar}}, 131.16 \mathrm{C}_{\mathrm{ar}}, 132.74 \mathrm{C}_{\mathrm{ar}}, 133.01 \mathrm{CH}_{\mathrm{ar}}$, $133.42 \mathrm{CH}_{\mathrm{ar}}, 135.71 \mathrm{C}_{\mathrm{pyr}} \mathrm{C}-\mathrm{NH}_{2}, 136.14 \mathrm{C}_{\mathrm{pyr}}-\mathrm{NH}_{2}, 161.02 \mathrm{COO}$.

\subsection{Biological Assay}

\subsubsection{Carbonic Anhydrase Purification and Inhibition Assays}

Affinity chromatography is a common and efficient method for separation of biochemical mixture based on a highly specific interaction between enzyme and substrate ${ }^{47}$. Sepharose-4B-LTyrosine-sulfanilamide (SBTS) material was used as a selective affinity matrix for retention of hCAs ${ }^{48-}$ 50. The most putative reaction catalyzed by hCAs is the conversion of p-nitrophenylacetate (PNA) into p-nitrophenol (PNP) and acetate. The hCAs activities were spectrophotometrically determined according to prior methods ${ }^{51,52}$. One hCA unit is a quantity of hCA, which had absorbance change of PNA to PNP at $348 \mathrm{~nm}$ over $3 \mathrm{~min}$ at $25^{\circ} \mathrm{C}^{54-56}$. During SBTS affinity chromatography processes, the quantity of hCAs was identified at $280 \mathrm{~nm}^{57,58}$ and the quantity of protein was measured at $595 \mathrm{~nm}^{59}$ as described previously ${ }^{60-62}$. Bovine serum was used as the standard protein ${ }^{63-64}$. The purity checking of hCA isozymes was performed at two different acrylamides concentrations (10 and 3\%) for running and the stacking gel, respectively, containing $0.1 \%$ sodium dodecyl sulphate according to Laemmle procedure $^{65}$ and described in prior studies ${ }^{66-69}$.

\subsubsection{Acetylcholinesterase Inhibition Assay}

The determination of novel enamine and pyrrole derivatives inhibition on AChE activity were conducted in line with spectrophotometric procedure recommended by Ellman et al. ${ }^{70}$ as described previously ${ }^{71,72}$. In both reactions, the substrates utilized were acetylthiocholine iodide (AChI) was conducted with maximum absorption at wavelength of $412 \mathrm{~nm}^{73-77}$.

\subsection{3. $\alpha$-Glycosidase Inhibition Assay}

$\alpha$-Glycosidase inhibition effect of novel enamine and pyrrole derivatives was realized using $\mathrm{p}$ nitrophenyl-D-glycopyranoside (pNPG) as the substrate, according to the prior procedure of Tao et al. ${ }^{78}$. The absorbances were spectrophotometrically recorded at $405 \mathrm{~nm}$. The $\mathrm{IC}_{50}$ was calculated from activity (\%) versus novel enamine and pyrrole derivatives concentration plots ${ }^{79-81}$.

\section{Results and Discussion}

\subsection{Chemistry}

New pyrrole and enamine derivatives containing ethyl ether fragment of acetate and glycyl acid, synthesized on the basis of two-component condensation, are a class of physiologically and pharmacologically favorable heterocyclic compounds. Taking into account the successful application of analogues of these compounds containing different functional groups in medicine, we have synthesized their new derivatives. First, (Z)-ethyl 2-(3-oxo-1,3-diphenylprop-1-enylamino)acetate (1) was obtained as a result of the reaction of dibenzoylmethane with glycine ethyl ester hydrochloride under the catalytic effect of $Y(O T F)_{3}$ in aqueous medium. Then enamine was taken as the object of study. It was dissolved in butyl alcohol and added to it tert-BuOK. The final result is crystals of ethyl-3,5-diphenyl-1H-pyrrole2-carboxylate (2). The reaction scheme can be described as follows (Scheme 1) 
Synthesis, characterization and bioactivity of novel enamine and pyrrole derivatives

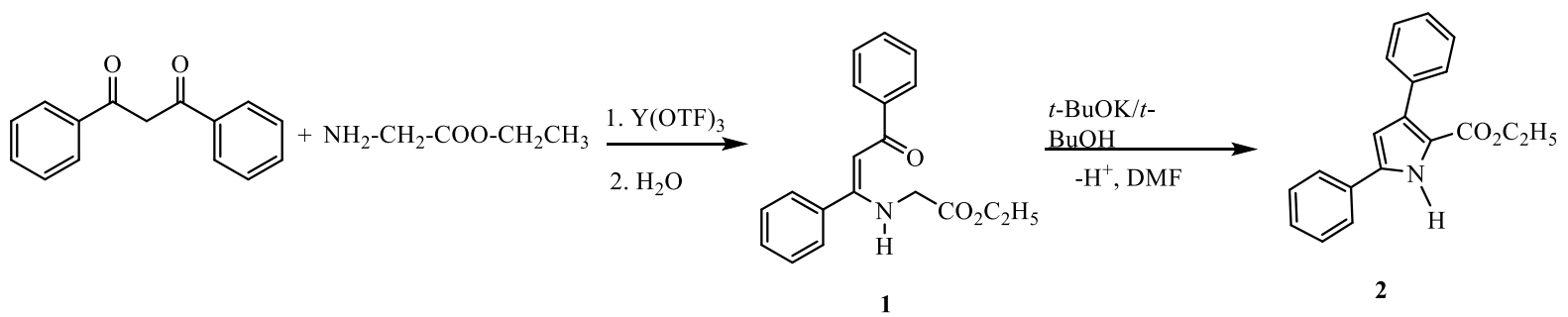

Scheme 1. Synthesis of (Z)-ethyl 2-(3-oxo-1,3-diphenylprop-1-enylamino)acetate (1) and ethyl-3,5diphenyl-1H-pyrrole-2-carboxylate (2)

\subsection{X-ray structural determination}

X-ray crystallographic analysis was performed by double crystallization of novel compound 2 in ethyl alcohol. The crystalline form and structure of compound $\mathbf{2}$ have been given in the Figure 1, but the selected difference between bond length and valence angle has been given in Supplemental Information. Crystalline compound $\mathbf{2}$ keep crystallographically independent molecules in the central bicyclic fragment. The compound $\mathbf{2}$ keep complex three-organic compound system consisting of pyrrole and benzol rings. Hydrogen bonds for A_A [ $\AA$ and ${ }^{\circ}$ ] were given in Table 2. In bicyclic fragment the cycles of pyrrole take a shape of symmetric platform. In this instance, benzol cycle in practice directs to the cycle of pyrrole perpendicularly.

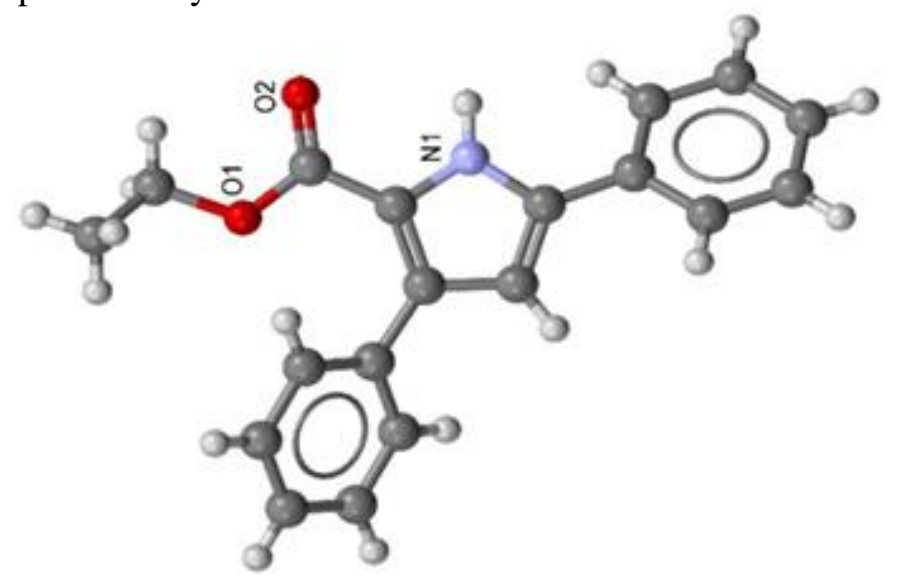

Figure 1. The molecular structure of the compound 2

Table 2. Hydrogen bonds for A_A $\left[\AA\right.$ and $^{\circ}$ ]

\begin{tabular}{|l|l|l|l|l|}
\hline D-H...A & d(D-H) & d(H...A) & d(D...A) & $<($ DHA) \\
\hline $\mathrm{N}(1)-\mathrm{H}(1 \mathrm{~N} 1) \ldots \mathrm{O}(1) \# 1$ & 0.90 & 2.09 & $2.947(3)$ & 158.2 \\
\hline
\end{tabular}

Symmetry transformations used for generation of equivalent atoms: \#1 -x+1,-y,-z+1

\subsection{Enzymes Inhibition Results}

In this study, the affinity chromatographic technique, in which the biological molecules contained in a complex mixture and desired to be purified are purified by using specific ligands by making use of some molecular properties of the proteins ${ }^{82,83}$. The hCAs were efficiently and successfully purified using the SBTS affinity chromatography method ${ }^{84-86}$. Classical inhibitors of CAs have been clinically employed as diuretic and anti-glaucoma drug in diabetics affected patients. Many researches have been studied on sulfonamides as CA inhibitors. They can be widespread used for treating diabetes, cancer, epilepsy and obesity ${ }^{87,88}$. In present study, the ubiquitous cytosolic hCA I was moderately inhibited by synthesized compounds. Both compounds exhibited $\mathrm{K}_{\mathrm{i}} \mathrm{s}$ in the low micromolar range. The order of the $\mathrm{K}_{\mathrm{i}} \mathrm{S}$ of the indicated compounds was $\mathbf{2}\left(\mathrm{K}_{\mathrm{i}}: 47.21 \pm 5.06 \mu \mathrm{M}\right)>\mathbf{1}\left(\mathrm{K}_{\mathrm{i}}: 85.07 \pm 10.04 \mu \mathrm{M}\right)$. Based on the $\mathrm{IC}_{50}$ and $\mathrm{K}_{\mathrm{i}}$ values of compounds $\mathbf{1}$ and $\mathbf{2}$ had less than inhibitory activity in comparison with the standard drug AZA $\left(\mathrm{K}_{\mathrm{i}}: 27.04 \pm 2.43 \mu \mathrm{M}\right)$ (Table 3). 
Table 3. The inhibition results of both compounds for hCAs, acetylcholinesterase (AChE) and $\alpha$-glycosidase enzymes

\begin{tabular}{|c|c|c|c|c|c|c|c|c|c|c|c|c|}
\hline \multirow{2}{*}{ Compounds } & \multicolumn{6}{|c|}{$\mathrm{IC}_{50}(\mu \mathrm{M})$} & \multicolumn{6}{|c|}{$K_{i}(\mu M)$} \\
\hline & hCA I & $\mathbf{r}^{2}$ & hCA II & $\mathbf{r}^{2}$ & AChE & $\mathbf{r}^{2}$ & $\alpha$-Gly & $\mathbf{r}^{2}$ & hCA I & hCA II & AChE & $\alpha$-Gly \\
\hline 1 & 78.05 & 0.9704 & 58.94 & 0.9820 & 206.43 & 0.9614 & 54.98 & 0.9036 & $85.07 \pm 10.04$ & $66.01 \pm 8.47$ & $154.87 \pm 15.85$ & $63.76 \pm 7.12$ \\
\hline 2 & 39.54 & 0.9726 & 30.15 & 0.9688 & 128.36 & 0.9881 & 91.11 & 0.9742 & $47.21 \pm 5.06$ & $35.77 \pm 3.53$ & $103.94 \pm 15.36$ & $93.54 \pm 11.20$ \\
\hline AZA & 21.42 & 0.9432 & 25.32 & 0.9631 & - & - & - & - & $27.04 \pm 2.43$ & $35.51 \pm 3.32$ & - & - \\
\hline TAC & - & - & - & - & 118.20 & 0.9547 & - & - & - & & $107.25 \pm 18.61$ & - \\
\hline ACR & - & - & - & - & - & - & 31.64 & 0.9202 & - & & - & $45.21 \pm 5.34$ \\
\hline
\end{tabular}

AZA: Acetazolamide; TAC: Tacrine; ACR: Acarbose were used as a positive control for hCAs, AChE and $\alpha$-glycosidase ( $\alpha$-Gly) enzymes 
CA II has significant role in biological processes such as homeostasis balance of $\mathrm{pH}$ and $\mathrm{CO}_{2}$, biosynthetic reactions, calcification, respiration and movement of carbon dioxide/bicarbonate, bone resorption, and tumorigenicity ${ }^{89,90}$. Treatment of glaucoma requires high doses of sulfonamide drugs and this sometimes results in various adverse impacts such as malaise, altered taste, depression, fatigue, and anorexia ${ }^{91}$. Son, we synthesized organic compounds based on non-sulfonamide moiety and investigation their role as inhibitors of hCA II isoenzyme in this study. According to the results, the order of the $\mathrm{K}_{\mathrm{i}} \mathrm{S}$ of the both synthesized compounds was following order: $\mathbf{2}\left(\mathrm{K}_{\mathrm{i}}: 35.77 \pm 3.53 \mu \mathrm{M}\right)$ and $\mathbf{1}\left(\mathrm{K}_{\mathrm{i}}: 66.01 \pm 8.47\right.$ $\mu \mathrm{M})$. Based on the $\mathrm{K}_{\mathrm{i}}$ values, compound $\mathbf{1}$ had less inhibitory activity when compared with AZA ( $\mathrm{K}_{\mathrm{i}}$ : 35.51 $\pm 3.32 \mu \mathrm{M})($ Table 3). Also, the compound 2 gave almost close results to AZA, which is a medication used for treatment of some common disease including glaucoma ${ }^{92,93}$.

$\mathrm{ACh}$ is the most significant neurotransmitter and had great importance in the regulation in body processes $^{94,95}$. Acetylcholinesterase inhibitors (AChEIs) have cholinergic deficit in AD by reestablishing the level of synaptic ACh. AChEIs have inhibited AChE activity and blocked ACh breakdown. Inhibition of AChE activity permits ACh to keep active in the synapse and to accumulate, which can give rise to deadly results such as respiratory failure central nervous system symptoms and coma until death for the most severe cases. So, AChEIs have clinically demonstrated beneficial effects in symptomatic $\mathrm{AD}$ treatment ${ }^{96}$. In this study, the inhibition effect of both novel enamine and pyrrole derivatives on AChE activity was investigated. The Lineweaver-Burk plots were used for determination inhibition type and $\mathrm{K}_{\mathrm{i}}$ parameters ${ }^{97,98}$. The order of the $\mathrm{K}_{\mathrm{i}} \mathrm{s}$ of the both synthesized compounds was 2 $\left(\mathrm{K}_{\mathrm{i}}: 103.94 \pm 15.36 \mu \mathrm{M}\right)$ and $\mathbf{1}\left(\mathrm{K}_{\mathrm{i}}: 154.87 \pm 15.85 \mu \mathrm{M}\right)$ (Table 3). Based on the $\mathrm{K}_{\mathrm{i}}$ values of compound $\mathbf{1}$ had less than inhibitory activity in comparison with the standard compound TAC $\left(\mathrm{K}_{\mathrm{i}}: 107.25 \pm 18.61\right.$ $\mu \mathrm{M})$, but the compound 2 showed potent inhibition effect according to $\mathrm{TAC}^{78}$.

Increased plasma glucose level is a crucial indicator of hydrolysis of carbohydrates such as starch and sucrose ${ }^{99,100}$. Two important hydrolase enzymes including $\alpha$-glucosidase and $\alpha$-amylase primarily catalyze this process. $\alpha$-Glycosidases are found on the brush edges of enterocytes and perform the hydrolysis of carbohydrate polymers ${ }^{101,102}$. It hydrolyzes sucrose and starch into glucose units, while $\alpha$-amylases specifically hydrolyzes internal $\alpha-1,4$-glycosidic bond of starch to yield glucose and maltose. The inhibitors of both digestive enzymes can reduce plasma post-prandial glucose levels in patients with type 2 -diabetes ${ }^{103,104}$. The present study was designed to evaluated compounds against $\alpha$ glucosidase activity. The order of the $\mathrm{K}_{\mathrm{i}} \mathrm{s}$ of the synthesized compounds was $\mathbf{1}\left(\mathrm{K}_{\mathrm{i}}: 63.76 \pm 7.12 \mu \mathrm{M}\right)$ and $2\left(\mathrm{~K}_{\mathrm{i}}: 93.54 \pm 11.20 \mu \mathrm{M}\right)($ Table 2$)$. Based on the $\mathrm{IC}_{50}$ and $\mathrm{K}_{\mathrm{i}}$ values, both compounds had less than inhibitory effects in comparison with acarbose $\left(\mathrm{K}_{\mathrm{i}}: 45.21 \pm 5.34 \mu \mathrm{M}\right)$, which used to treat type 2-diabetes. Acarbose is a starch blocker and inhibits intestinal enzyme of $\alpha$-glucosidase that releases glucose from larger carbohydrates ${ }^{105}$.

\section{Conclusion}

(Z)-Ethyl 2-(3-oxo-1,3-diphenylprop-1-enylamino)acetate (1) and ethyl-3,5-diphenyl-1Hpyrrole-2-carboxylate (2) effectively inhibited the hCA I and II isoenzymes, $\alpha$-glycosidase and AChE enzymes at the micromolar levels. The inhibition of these enzymes is associated with some global health disturbances. So, both compounds can be acceptable candidate drugs for treatment of disorders including epilepsy, diabetes mellitus, duodenal and gastric ulcers, glaucoma, mountain sickness, Alzheimer's diseases, neurological diseases, and osteoporosis disturbances.

\section{Acknowledgements}

S.A would like to extend his sincere appreciation to the Researchers Supporting Project (RSP2021/59), King Saud University, Saudi Arabia.

\section{Supporting Information}

Supporting information accompanies this paper on https://www.acgpubs.org/journal/organic$\underline{\text { communications }}$ 
Synthesis, characterization and bioactivity of novel enamine and pyrrole derivatives

\section{ORCID}

Abel Maharramov: 0000-0003-1882-7519

Malahat Kurbanova: 0000-0001-9857-9505

Parham Taslimi : 0000-0002-3171-0633

Yeliz Demir: 0000-0003-3216-1098

Aytan Safarova: 0000-0002-1034-9308

Elnur Huseyinov: 0000-0001-5309-0124

Afsun Sujayev : 0000-0001-6890-2324

Saleh H. Alwasel: 0000-0002-0626-2306

İlhami Gülçin: 0000-0001-5993-1668

\section{References}

[1] Bhardwaj, V.; Gumber, D.; Abbot, V.; Dhimana, S.; Sharmaa, P. Pyrrole: A resourceful small molecule in key medicinal hetero-aromatics. RSC Adv. 2015, 5, 15233-15266.

[2] Saito, A.; Kanishi, T.; Hanzaw, Y. Synthesis of pyrroles by gold(I)-catalyzed aminoclaisen rearrangement of n-propargyl enaminone derivatives. Org. Lett. 2010, 12, 372-374.

[3] Oldfield, E. Targeting isoprenoid biosynthesis for drug discovery: Bench to bedside. Acc. Chem. Res. 2010, 143, 1216-1226.

[4] Khajuria, R.; Kapoor, K.K. One-pot, solvent-free cascade Michaelreductive cyclization reaction for the synthesis of ethyl 3,5-disubstituted-1H-pyrrole-2carboxylates under microwave irradiation. Curr. Microw. Chem. 2014, 1, 110-118.

[5] Khajuria, R.; Saini, Y.; Kapoor, K.K. A solvent-free synthesis of ethyl 3,5-diaryl1H-pyrrole-2-carboxylates via triethylphosphite mediated reductive cyclization of ethyl 2-nitro-5-oxo-3,5-diarylpentanoates under microwave irradiation. Tetrahedron Lett. 2013, 54, 5699-5702.

[6] Imbri, D.; Netz, N.; Kucukdisli, M.; Kammer, L.M.; Jung, P.; Kretzschmann, A.; Opatz, T. One-pot synthesis of pyrrole-2-carboxylates and-carboxamides via an electrocyclization/oxidation sequence. J. Org. Chem. 2014, 79, 11750-11758.

[7] Gatta, F.; Del Giudice, M.R.; Pomponi, M.; Marta, M. Synthesis of 1,2,3,4-tetrahydroacrine and 5,6,7,8tetrahydroquinoline derivates as potential actylcholinesterase inhibitors. Heterocycles 1992, 34, 991-1004.

[8] Scott, K.R.; Edafiogho, I.O.; Richardson, E.C.; Farrar, V.A.; Moore, J.A.; Tietz, E.I.; Hinko, C.N.; Chang, H.; El-Assadi, A.; Nicholson, J.M. Synthesis and anticonvulsant activity of enaminones. 2. Further structureactivity correlations. J. Med. Chem. 1993, 36, 1947-1955.

[9] Dondoni, A.; Perrone, D. 2-Thiazolyl $\alpha$-Amino Ketones: A new class of reactive intermediates for the stereocontrolled synthesis of unusual amino acids. Synthesis, 1993, 11, 1162-1176.

[10] Demir, A.C.; Akhmedov, I.M.; Sesenoqlu, O. Synthesis of 1,2,3,5-tetrasubstituted pyrrole derivatives from 2-(2-bromoallyl)-1,3-dicarbonyl compounds. Tetrahedron, 2002, 58, 9793-9799.

[11] Boddeti, G.; Bhagavathula, S.; Murthy, Y.L.N. A brief review on synthesis and application of $\beta$-enamino carbonyl compounds. Org. Commun. 2012, 5, 105-119.

[12] Tuğrak, M.; Gül, H.İ.; Demir, Y.; Levent, S.; Gulcin, I. Synthesis and in vitro carbonic anhydrases and acetylcholinesterase inhibitory activities of novel imidazolinone-based benzenesulfonamides. Arch. Pharm. 2021, 354 (4), e2000375.

[13] Cetinkaya, Y.; Göçer, H.; Gulcin, I.; Menzek, A. Synthesis and carbonic anhydrase isoenzymes inhibitory effects of brominated diphenylmethanone and its derivatives. Arch. Pharm. 2014, 347, 354-359.

[14] Bayrak, C.; Taslimi, P.; Gulcin, I.; Menzek, A. The first synthesis of 4-phenylbutenone derivative bromophenols including natural products and their inhibition profiles for carbonic anhydrase, acetylcholinesterase and butyrylcholinesterase enzymes. Bioorg. Chem. 2017, 72, 359-366.

[15] Hisar, O.; Beydemir, Ş.; Gulcin, I.; Küfrevioğlu, Ö.İ.; Supuran C.T. Effect of low molecular weight plasma inhibitors of rainbow trout (Oncorhyncytes mykiss) on human erythrocytes carbonic anhydrase-II isozyme activity in vitro and rat erythrocytes in vivo. J. Enzyme Inhib. Med. Chem. 2005, 20, 35-39.

[16] Karimov, A.; Orujova, A.; Taslimi, P.; Sadeghian, N.; Mammadov B.; Karaman H.S.; Farzaliyev V.; Sujayev E.; Taş R.; Alwasel S.; Gulcin I. Novel functionally substituted esters based on sodium diethyldithiocarbamate derivatives: synthesis, characterization, biological activity and molecular docking studies. Bioorg Chem. 2020, 99, 103762.

[17] Aktas, A.; Barut Celepci, D.; Gök, Y.; Taslimi, P.; Akıncıoğlu, H.; Gulcin, I. A novel Ag-N-heterocyclic carbene complex bearing the hydroxyethyl ligand: synthesis, characterization, crystal and spectral structures and bioactivity properties. Crystals, 2020, 10, 171. 
[18] Oztaskin, N.; Taslimi, P.; Maras, A.; Göksu, S.; Gulcin, I. Novel antioxidant bromophenols with acetylcholinesterase, butyrylcholinesterase and carbonic anhydrase inhibitory actions. Bioorg. Chem. 2017, 74, 104-114.

[19] Çağlayan, C.; Demir, Y.; Küçükler, S.; Taslimi, P.; Kandemir, F.M.; Gulcin, I. The effects of hesperidin on sodium arsenite-induced different organ toxicity in rats on metabolic enzymes as antidiabetic and anticholinergics potentials: A biochemical approach. J. Food Biochem. 2019, 43(2), e12720.

[20] Burmaoğlu, S.; Akın Kazancioglu, E.; Kaya, R.; Kazancioglu, M.; Karaman, M.; Algül, O.; Gulcin, I. Synthesis of novel organohalogen chalcone derivatives and screening of their molecular docking study and some enzymes inhibition effects. J. Mol. Struct. 2020, 1208, 127868.

[21] Gül, H.I.; Tuğrak, M.; Sakagami, H.; Taslimi, P.; Gulcin, I.; Supuran, C.T. Synthesis and bioactivity studies on new 4-(3-(4-substitutedphenyl)-3a,4-dihydro-3h-indeno[1,2-c]pyrazol-2-yl) benzenesulfonamides. $J$. Enzyme Inhib. Med. Chem. 2016, 31(6), 1619-1624.

[22] Yamali, C.; Gul, HI.; Kazaz, C.; Levent, S.; Levent, S.; Gulcin, I. Synthesis, structure elucidation, and in vitro pharmacological evaluation of novel polyfluoro substituted pyrazoline type sulfonamides as multi-target agents for inhibition of acetylcholinesterase and carbonic anhydrase I and II enzymes. Bioorg. Chem. 2020, 96, 103627.

[23] Ozbey, F.; Taslimi, P.; Gulcin, I.; Maraş, A.; Goksu, S.; Supuran, C.T. Synthesis, acetylcholinesterase, butyrilcholinesterase, carbonic anhydrase inhibitory and metal chelating properties of some novel diaryl ether. J. Enzyme Inhib. Med. Chem. 2016, 31(S2), 79-85.

[24] Yigit, M.; Yigit, B.; Taslimi, P.; Ozdemir, I.; Karaman, M.; Gulcin, I. Novel amine-functionalized benzimidazolium salts: Synthesis, characterization, bioactivity, and molecular docking studies. J. Mol. Struct. 2020, $1207,127802$.

[25] Buldurun, K.; Turan, N.; Bursal, E.; Mantarc1, A.; Turkan, F.; Taslimi, P.; Gulcin, I. Synthesis, spectroscopic properties, crystal structures, antioxidant activities and enzyme inhibition determination of $\mathrm{Co}$ (II) and $\mathrm{Fe}$ (II) complexes of Schiff base. Res. Chem. Intermed. 2020, 46, 283-297.

[26] Bilginer, S.; Gul, H.I.; Erdal, F.S.; Sakagami, H.; Levent, S.; Gulcin, I.; Supuran, C.T. Synthesis, cytotoxicities, and carbonic anhydrase inhibition potential of 6-(3-aryl-2-propenoyl)-2(3H)-benzoxazolones. J. Enzyme Inhib. Med. Chem. 2019, 34, 1722-1729.

[27] Sujayev, A.; Taslimi, P.; Kaya, R.; Safarov, B.; Aliyeva, L.; Farzaliyev, V.; Gulcin, I. Synthesis, Characterization and biological evaluation of N-substituted triazinane-2-thiones and theoretical-experimental mechanism of condensation reaction. Appl. Organomet. Chem. 2020, 34, e5329.

[28] Bal, S.; Kaya, R.; Taslimi, P.; Aktaş, A.; Karaman, M.; Gulcin, I. Novel 2-methylimidazolium salts: synthesis, characterization, molecular docking, and carbonic anhydrase and acetylcholinesterase inhibitory properties. Bioorg. Chem. 2020, 94, 103468.

[29] Gül, HI.; Tuğrak, M.; Gül, M.; Mazlumoğlu, S.; Sakagami, H.; Gulcin, I.; Supuran, C.T. New phenolic mannich bases with piperazines and their bioactivities. Bioorg. Chem. 2019, 90, 103057.

[30] Küçükoğlu, K.; Gül, H.İ.; Taslimi, P.; Gulcin, I.; Supuran, C.T. Investigation of inhibitory properties of some hydrazone compounds on hCA I, hCA II and AChE enzymes. Bioorg. Chem. 2019, 86, 316-321.

[31] Burmaoğlu, S.; Yılmaz, A.O.; Polat, M.F.; Algül, O.; Kaya, R.; Gulcin, I. Synthesis and biological evaluation of novel tris-chalcones as potent carbonic anhydrase, acetylcholinesterase, butyrylcholinesterase, and $\alpha$ glycosidase inhibitors. Bioorg. Chem. 2019, 85, 191-197.

[32] Ozmen Ozgün, D.; Gül, H.I.; Yamali, C.; Sakagami, H.; Gulcin, I.; Sukuroglu, M.; Supuran, C.T. Synthesis and bioactivities of pyrazoline benzensulfonamides as carbonic anhydrase and acetylcholinesterase inhibitors with low cytotoxicity. Bioorg. Chem. 2019, 84, 511-517.

[33] Bayrak, Ç.; Taslimi, P.; Kahraman, H.S.; Gulcin, I.; Menzek, A. The first synthesis, carbonic anhydrase inhibition and anticholinergic activities of some bromophenol derivatives with $\mathrm{S}$ including natural products. Bioorg. Chem. 2019, 85, 128-139.

[34] Yiğit, B.; Yiğit, M.; Taslimi, P.; Gok, Y.; Gulcin, I. Schiff bases and their amines: synthesis, and discovery of carbonic anhydrase and acetylcholinesterase enzymes inhibitors. Arch. Pharm. 2018, 351, e1800146.

[35] Atmaca, U.; Yıldırım, A.; Tuncel Çelik, S.; Gulcin, I.; Supuran, C.T.; Çelik, M. Intermolecular amination of allylic and benzylic alcohols leads to effective inhibitions of acetylcholinesterase enzyme and carbonic anhydrase I and II isoenzymes. J. Biochem. Mol. Toxicol. 2018, 32, e22173.

[36] Burmaoglu, S.; Yilmaz, A.O.; Taslimi, P.; Algul, O.; Kılıç, D.; Gulcin, I, Synthesis and biological evaluation of phloroglucinol derivatives possessing $\alpha$-glycosidase, acetylcholinesterase, butyrylcholinesterase, carbonic anhydrase inhibitory activity. Arch. Pharm. 2018, 351, e1700314. 
Synthesis, characterization and bioactivity of novel enamine and pyrrole derivatives

[37] Genc Bilgicli, H.; Ergon, D.; Taslimi, P.; Tuzun, B.; Akyazı Kuru, I.; Zengin, M.; Gulcin, I. Novel propanolamine derivatives attached to 2-metoxifenol moiety: Synthesis, characterization, biological properties, and molecular docking studies. Bioorg. Chem. 2020, 101, 103969.

[38] Lolak, N.; Akocak, S.; Turkes, C.; Taslimi, P.; Isik, M.; Beydemir, Ş.; Gulcin, I.; Durgun, M. Synthesis, characterization, inhibition effects, and molecular docking studies as acetylcholinesterase, $\alpha$-glycosidase, and carbonic anhydrase inhibitors of novel benzenesulfonamides incorporating 1,3,5-triazine structural motifs. Bioorg. Chem. 2020, 100, 103897.

[39] Artunç, T.; Menzek, A.; Taslimi, P.; Gulcin, I.; Kazaz, C.; Sahin, E. Synthesis and antioxidant activities of phenol derivatives from 1,6-bis(dimethoxyphenyl)hexane-1,6-dione. Bioorg. Chem. 2020, 100, 103884.

[40] Gulcin, I.; Kaya, R.; Gören, A.C.; Akıncıoğlu, H.; Topal, M.; Bingöl, Z.; Çetin Çakmak, K.; Ozturk Sarikaya, S.B.; Durmaz, L.; Alwasel, S, Anticholinergic, antidiabetic and antioxidant activities of Cinnamon (Cinnamomum verum) bark extracts: Polyphenol contents analysis by LC-MS/MS. Int. J. Food Prop. 2019, 22, 1511-1526.

[41] Demir, Y.; Durmaz, L.; Taslimi, P.; Gulcin, I. Anti-diabetic properties of dietary phenolic compounds: inhibition effects on $\alpha$-amylase, aldose reductase and $\alpha$-glycosidase. Biotechnol. Appl. Biochem. 2019, 66, 781-786.

[42] Mamedova, G.; Mahmudova, A.; Mamedov, S.; Erden, Y.; Taslimi, P.; Tüzün, B.; Taş, R.; Farzaliyev, V.; Sujayev, A.; Alwasel, S.H.; Gulcin, I. Novel tribenzylaminobenzolsulphonylimine based on their pyrazine and pyridazines: synthesis, characterization, antidiabetic, anticancer, anticholinergics, and molecular docking studies. Bioorg. Chem. 2019, 93, 103313.

[43] Sheldrick, G.M. The SHELX programs for crystal structure determination are reviewed by their author. Acta Cryst. 2008, 64, 112-122.

[44] Farrugia, L.J. WinGX suite for small-molecule single-crystal crystallography. J. Appl. Cryst. 1999, 32, 837838.

[45] Mercury, Version 3.0, CCDC, ccdc.cam.ac.uk/products/mercury, 2000.

[46] Spek, A.L. Utrecht University, Utrecht, 2005.

[47] Aizpurua-Olaizola, O.; Sastre Torano, J.; Pukin, A.; Fu, O.; Boons, GJ.; de Jong, GJ.; Pieters, R.J. Affinity capillary electrophoresis for the assessment of binding affinity of carbohydrate-based cholera toxin inhibitors. Electrophoresis, 2018, 39, 344-347.

[48] Taslimi, P.; Turkan, F.; Cetin, A.; Burhan, H.; Karaman, M.; Bildirici, İ.; Gulcin, I.; Şen, F. Pyrazole[3,4d]pyridazine derivatives: Molecular docking and explore of acetylcholinesterase and carbonic anhydrase enzymes inhibitors as anticholinergics potentials. Bioorg. Chem. 2019, 92, 103213.

[49] Caglayan, C.; Taslimi, P.; Türk, C.; Kandemir, F.M.; Demir, Y.; Gulcin, I. Purification and characterization of the carbonic anhydrase enzyme from horse mackerel (Trachurus trachurus) muscle and the impact of some metal ions and pesticides on enzyme activity. Comp. Biochem. Physiol. C. 2019, 226, 108605.

[50] Kucuk, M.; Gulcin, I. Purification and characterization of carbonic anhydrase enzyme from black sea trout (Salmo trutta Labrax Coruhensis) kidney and inhibition effects of some metal ions on the enzyme activity. Environ. Toxicol. Pharmacol. 2016, 44, 134-139.

[51] Akıncıoğlu, A.; Kocaman, E.; Akıncığlu, H.; Salmas, R.E.; Durdağı, S.; Gulcin, I.; Supuran, CT.; Göksu, S. The synthesis of novel sulfamides derived from $\beta$-benzylphenethylamines as acetylcholinesterase, butyrylcholinesterase and carbonic anhydrase enzymes inhibitors. Bioorg Chem. 2017, 74, 238-250.

[52] Akıncıoğlu, A.; Akıncıŏglu, H.; Gulcin, I.; Durdağı, S.; Supuran, C.T.; Göksu, S. Discovery of potent carbonic anhydrase and acetylcholine esterase inhibitors: Novel sulfamoylcarbamates and sulfamides derived from acetophenones. Bioorg. Med. Chem. 2015, 23, 3592-3602.

[53] Gocer, H.; Topal, F.; Topal, M.; Küçük, M.; Teke, D.; Gulcin, I.; Alwasel, S.H.; Supuran, C.T.; Acetylcholinesterase and carbonic anhydrase isoenzymes I and II inhibition profiles of taxifolin. J. Enzyme Inhib. Med. Chem. 2016, 31, 441-447.

[54] Ozgeriş, B.; Göksu, S.; Köse Polat, L.; Gulcin, I.; Salmas, R.E.; Durdagi, S.; Tümer, F.; Supuran, C.T. Acetylcholinesterase and carbonic anhydrase inhibitory properties of novel urea and sulfamide derivatives incorporating dopaminergic 2-aminotetralin scaffolds. Bioorg. Chem. 2016, 24, 2318-2329.

[55] Gulcin, I.; Scozzafava, A.; Supuran, C.T.; Akıncıoğlu, H.; Koksal, Z.; Turkan, F.; Alwasel, S. The effect of caffeic acid phenethyl ester (CAPE) metabolic enzymes including acetylcholinesterase, butyrylcholinesterase, glutathione S-transferase, lactoperoxidase and carbonic anhydrase isoenzymes I, II, IX and XII. J. Enzyme Inhib. Med. Chem. 2016, 31, 1095-1101.

[56] Yılmaz, S.; Akbaba, Y.; Özgeriş, B.; Polat Köse, L.; Göksu, S.; Gulcin, I.; Alwasel, S.H.; Supuran, C.T. Synthesis and inhibitory properties of some carbamates on carbonic anhydrase and acetylcholine esterase. $J$. Enzyme Inhib. Med. Chem. 2016, 31, 1484-1491.

[57] Taslimi, P.; Turhan, K.; Turkan, F.; Karaman, H.S.; Turgut, Z.; Gulcin, I. Cholinesterases, $\alpha$-glycosidase, and carbonic anhydrase inhibition properties of $1 \mathrm{H}$-pyrazolo[1,2-b]phthalazine-5,10-dione derivatives: 
Synthetic analogues for the treatment of Alzheimer's disease and diabetes mellitus. Bioorg. Chem. 2020, 97, 103647.

[58] Bytyqi-Damoni, A.; Kestane, A.; Taslimi, P.; Tuzun, B.; Zengin, M.; Genç Bilgiçli, H.; Gulcin, I. Synthesis of novel $\beta$-amino carbonyl derivatives and their inhibition effects on some metabolic enzymes. J. Mol. Struct. 2020, 1202, 127297.

[59] Bradford, M.M. A rapid and sensitive method for the quantitation of microgram quantities of protein utilizing the principle of protein-dye binding. Anal. Biochem. 1976, 72, 248-251.

[60] Biçer, A.; Kaya, R.; Yakali, G.; Gültekin, M.S.; Turgut Cin, G.; Gulcin, I. Synthesis of novel $\beta$-amino carbonyl derivatives and their inhibition effects on some metabolic enzymes. J. Mol. Struct. 2020, 1204, 127453.

[61] Yıldırım, A.; Atmaca, U.; Keskin, A.; Topal, M.; Çelik, M.; Gulcin, I.; Supuran, C.T. N-Acylsulfonamides strongly inhibit human carbonic anhydrase isoenzymes I and II. Bioorg. Med. Chem. 2015, 23, 2598-2605.

[62] Atasever, A.; Özdemir, H.; Gulcin, I.; Küfrevioğlu Ö.İ. One-step purification of lactoperoxidase from bovine milk by affinity chromatography. Food Chem. 2013, 136, 864-870.

[63] Gulcin, I.; Beydemir, S. Phenolic compounds as antioxidants: Carbonic anhydrase isoenzymes inhibitors. Mini Rev. Med. Chem. 2013, 13, 408-430.

[64] Akıncıoğlu, A.; Akbaba, Y.; Göçer, H.; Göksu, S.; Gulcin, I.; Supuran, C.T. Novel sulfamides as potential carbonic anhydrase isoenzymes inhibitors. Bioorg. Chem. 2013, 21, 1379-1385.

[65] Laemmli, D.K. Cleavage of structural proteins during the assembly of the head of bacteriophage T4. Nature 1970, 227, 680-683.

[66] Aksu, K.; Nar, M.; Tanç, M.; Vullo, D.; Gulcin, I.; Göksu, S.; Tümer, F.; Supuran, C.T. Synthesis and carbonic anhydrase inhibitory properties of sulfamides structurally related to dopamine. Bioorg. Med. Chem. 2013, 21, 2925-2931.

[67] Akbaba, Y.; Akıncıoğlu, A.; Göçer, H.; Göksu, S.; Gulcin, I.; Supuran, C.T. Carbonic anhydrase inhibitory properties of novel sulfonamide derivatives of aminoindanes and aminotetralins. J. Enzyme Inhib. Med. Chem. 2014, 29, 35-42.

[68] Topal, M.; Gulcin, I. Rosmarinic acid: a potent carbonic anhydrase isoenzymes inhibitor. Turk. J. Chem. 2014, 38, 894-902.

[69] Arabaci, B.; Gulcin, I.; Alwasel, S. Capsaicin: A potent inhibitor of carbonic anhydrase isoenzymes. Molecules 2014, 19, 10103-10114.

[70] Ellman, G.L.; Courtney, K.D.; Andres, V.; Featherston, R.M. A new and rapid colorimetric determination of acetylcholinesterase activity. Biochem. Pharmacol. 1961, 7, 88-95.

[71] Göçer, H, Akıncıoğlu, A, Göksu, S, Gulcin, I, Supuran, C.T. Carbonic anhydrase and acetylcholine esterase inhibitory effects of carbamates and sulfamoylcarbamates. J. Enzyme Inhib. Med. Chem. 2015, 30, 316-320.

[72] Karakaya, S, Bingol, Z, Koca, M, Dagoglu, S, Pınar, N.M, Demirci, B, Gulcin, I, Brestic M, Sytar O, Identification of non-alkaloid natural compounds of Angelica purpurascens (Avé-Lall.) Gilli. (Apiaceae) with acetylcholinesterase and cholinesterase inhibition potential. Saudi Pharm. J. 2020, 28, 1-14.

[73] El-Sayed, N.A.E.; Farag, A.E.S.; Ezzat, M.A.F.; Akincioglu, H.; Gulcin, I.; Abou-Seri, S.M. Design, synthesis, in vitro and in vivo evaluation of novel pyrrolizine-based compounds with potential activity as cholinesterase inhibitors and anti-Alzheimer's agents. Bioorg. Chem. 2019, 93, 103312.

[74] Genç, H.; Kalin, R.; Köksal, Z.; Sadeghian, N.; Kocyigit, U.M.; Zengin, M.; Gulcin, I.; Ozdemir, H. Discovery of potent carbonic anhydrase and acetylcholinesterase inhibitors: 2-aminoindan $\beta$-lactam derivatives. Int. J. Mol. Sci. 2016, 17, 1736.

[75] Topal, M. Secondary metabolites of ethanol extracts of Pinus sylvestris cones from eastern anatolia and their antioxidant, cholinesterase and $\alpha$-glucosidase activities. Rec. Nat. Prod. 2019, 14(2), 129-138.

[76] Şenol, H.; Çokuludağ, K.; Sena Aktaş, A.; Atasoy, S.; Dağ, A.; Topçu, G. Synthesis of new fatty acid derivatives of oleanane and ursane triterpenoids and investigation of their in vitro cytotoxic effects on 3T3 fibroblast and PC3 prostate cancer cell lines. Org. Commun. 2020, 13(3), 114-126.

[77] Polat Kose, L.; Gulcin, I. Inhibition effects of some lignans on carbonic anhydrase, acetylcholinesterase and butyrylcholinesterase enzymes. Rec. Nat. Prod. 2017, 11(6), 558-561.

[78] Tao, Y.; Zhang, Y.F.; Cheng, Y.Y.; Wang, Y. Rapid screening and identification of alpha-glucosidase inhibitors from mulberry leaves using enzyme- immobilized magnetic beads coupled with HPLC/MS and NMR. Biomed. Chromatogr. 2013, 27, 148-155.

[79] Taslimi, P.; Gulcin, I. Antioxidant and anticholinergic properties of olivetol. J. Food Biochem. 2018, 42, e12516.

[80] Oztaşkın, N.; Çetinkaya, Y.; Taslimi, P.; Göksu, S.; Gulcin, I. Antioxidant and acetylcholinesterase inhibition properties of novel bromophenol derivatives. Bioorg. Chem. 2015, 60, 49-57. 
Synthesis, characterization and bioactivity of novel enamine and pyrrole derivatives

[81] Polat Köse, L.; Gulcin, I.; Gören, A.C.; Namiesnik, J.; Martinez-Ayala, A.L.; Gorinstein, S. LC-MS/MS analysis, antioxidant and anticholinergic properties of galanga (Alpinia officinarum Hance) rhizomes. Ind. Crop. Prod. 2015, 74, 712-721.

[82] Pedrood, K.; Sherefati, M.; Taslimi, P.; Mohammadi-Khanaposhtani, M.; Asgari, M.S.; Hosseini, S.; Rastegar, H.; Larijani, B.; Mahdavi, M.; Taslimi, P.; Erden, Y.; Günay, S.; Gulçin, İ. Design, synthesis, characterization, enzymatic inhibition evaluations, and docking study of novel quinazolinone derivatives. Int. J. Biol. Macromol. 2021, 170, 1-12.

[83] Scozzafava, A.; Kalın, P.; Supuran, CT.; Gulcin, I.; Alwasel, S. The impact of hydroquinone on acetylcholine esterase and certain human carbonic anhydrase isoenzymes (hCA I, II, IX, and XII). J. Enzyme Inhib. Med. Chem. 2015, 30, 941-946.

[84] Garibov, E.; Taslimi, P.; Sujayev, A.; Bingöl, Z.; Çetinkaya, S.; Gulcin, I.; Beydemir, S.; Farzaliyev, V.; Alwasel, S.H.; Supuran, C.T. Synthesis of 4,5-disubstituted-2-thioxo-1,2,3,4-tetrahydropyrimidines and investigation of their acetylcholinesterase, butyrylcholinesterase, carbonic anhydrase I/II inhibitory and antioxidant activities. J. Enzyme Inhib. Med. Chem. 2016, 31(S3), 1-9.

[85] Kucukoglu, K.; Oral, F.; Aydin, T.; Yamali, C.; Algul, O.; Sakagami, H.; Gulcin, I.; Supuran, C.T.; Gul, H.I. Synthesis, cytotoxicity and carbonic anhydrase inhibitory activities of new pyrazolines. J. Enzyme Inhib. Med. Chem. 2016, 31(S4): 20-24.

[86] Gulcin, I.; Trofimov, B.; Kaya, R.; Taslimi, P.; Sobenina, L.; Schmidt, E.; Petrova, O.; Malysheva, S.; Gusarova, N.; Farzaliyev V.; Sujayev A.; Alwasel S, Supuran C.T. Synthesis of nitrogen, phosphorus, selenium and sulfur-containing heterocyclic compounds-determination of their carbonic anhydrase, acetylcholinesterase, butyrylcholinesterase and $\alpha$-glucosidase inhibition properties. Bioorg. Chem. 2020, 103, 104171.

[87] Okten, S.; Aydın, A.; Koçyiğit, U.M.; Çakmak, O.; Erkan, S.; Andac, C.A.; Taslimi, P.; Gulcin, I. Quinolinebased promising anticancer and antibacterial agents, and some metabolic enzymes inhibitors. Arch. Pharm. 2020, 353(9), e2000086.

[88] Dasgin, S.; Gok, Y.; Barut Celepci, D.; Taslimi, P.; İzmirli, M.; Aktaş, A.; Gulçin, İ. Synthesis, characterization, crystal structure and bioactivity properties of the benzimidazole-functionalized PEPPSI type of Pd(II)NHC complexes. J. Mol. Struct. 2020, 1228, 129442.

[89] Yamali, C.; Gül, H.I.; Demir, Y.; Kazaz, C.; Gulcin, I. Synthesis and bioactivities of 1-(4-hydroxyphenyl)2-((heteroaryl)thio)ethanones as carbonic anhydrase I, II and acetylcholinesterase inhibitors. Turk. J. Chem. 2020, 44, 1058-1067.

[90] Gul, H.I.; Mete, E.; Taslimi, P.; Gulcin, I.; Supuran, C.T. Synthesis, carbonic anhydrase I and II inhibition studies of the 1,3,5-trisubstituted-pyrazolines. J. Enzyme Inhib. Med. Chem. 2017, 32, 189-192.

[91] Aktaş, A.; Celepci, D.B.; Kaya, R.; Taslimi, P.; Gök, Y.; Aygün, M.; Gulcin, I. Novel morpholine liganded Pd-based N-heterocyclic carbene complexes: Synthesis, characterization, crystal structure, antidiabetic and anticholinergic properties. Polyhedron, 2019, 159, 345-354.

[92] Erdemir, F.; Barut, Celepci, D.; Aktas, A.; Gök, Y.; Kaya, R.; Taslimi, P.; Demir, Y.; Gulcin, I. Novel $2-$ aminopyridine liganded $\mathrm{Pd}(\mathrm{II}) \mathrm{N}$-heterocyclic carbene complexes: synthesis, characterization, crystal structure and bioactivity properties. Bioorg. Chem. 2019, 91, 103134.

[93] Isık, M.; Akocak, S.; Lolak, N.; Taslimi, P.; Turkes, C.; Gulcin, I.; Durgun, M.; Beydemir, S. Synthesis, characterization, biological evaluation, and in silico studies of novel 1,3-diaryltriazene-substituted sulfathiazole derivatives. Arch. Pharm. 2020, 353(9), e2000102.

[94] Demir, Y.; Taslimi, P.; Ozaslan, M.S.; Oztaskın, N.; Çetinkaya, Y.; Gulcin, I.; Beydemir, S.; Göksu, P. Antidiabetic potential: In vitro inhibition effects of bromophenol and diarylmethanones derivatives on metabolic enzymes. Arch. Pharm. 2018, 351(12), e1800263.

[95] Bal, S.; Demirci, Ö.; Aktaş, A.; Şen, B.; Taslimi, P.; Aktaş, A.; Gök, Y.; Aygün, M.; Gulçin, İ. PEPPSI type $\mathrm{Pd}(\mathrm{II})$ NHC complexes bearing Chloro-/Fluorobenzyl group: Synthesis, characterization, crystal structures, $\alpha$-glycosidase and acetylcholinesterase inhibitory properties. Polyhedron, 2021, 198, 115060.

[96] Günsel, A.; Yaşa Atmaca, G, Taslimi, P.; Bilgiçli, A.T.; Gulçin, İ.; Erdoğmuş, A.; Yaraşır, M.N. Synthesis, characterization, photo-physicochemical and biological properties of water-soluble tetra-substituted phthalocyanines: Antidiabetic, anticancer and anticholinergic potentials. J. Photoch. Photobiol. A 2020, 396, 112511.

[97] Gulcin, I.; Tel, A.Z.; Goren, A.C.; Taslimi, P.; Alwasel, S. Sage (Salvia pilifera): Determination its polyphenol contents, anticholinergic, antidiabetic and antioxidant activities. J. Food Measure. Charac. 2019, 13(3), 2062-2074.

[98] Gulcin, I.; Taslimi, P.; Aygün, A.; Sadeghian, N.; Bastem, E.; Kufrevioglu, O.I.; Turkan, F.; Şen, F. Antidiabetic and antiparasitic potentials: inhibition effects of some natural antioxidant compounds on $\alpha-$ glycosidase, $\alpha$-amylase and human glutathione S-transferase enzymes. Int. J. Biol. Macromol. 2018, 119, 741-746. 
[99] Bursal, E.; Aras, A.; Kılıç, Ö.; Taslimi, P.; Gören, A.C.; Gulcin, I. Phytochemical content, antioxidant activity, and enzyme inhibition effect of Salvia eriophora Boiss. \& Kotschy against acetylcholinesterase, $\alpha$ amylase, butyrylcholinesterase, and $\alpha$-glycosidase enzymes. J. Food Biochem. 2019, 43(3), e12776.

[100] Morocho, V.; Sarango, D.; Cruz-Erazo, C.; Cumbicus, N.; Cartuche, L.; Suárez, A.I. Chemical constituents of Croton thurifer Kunth as $\alpha$-glucosidase inhibitors. Rec. Nat. Prod. 2019,14, 31-41.

[101] Demir, Y.; Duran, H.E.; Durmaz, L.; Taslimi, P.; Beydemir, S.; Gulcin, I. The influence of some nonsteroidal anti-inflammatory drugs on metabolic enzymes of aldose reductase, sorbitol dehydrogenase, and a-glycosidase: A perspective for metabolic disorders. Appl. Biochem. Biotechnol. 2020, 190(2), $437-$ 447.

[102] Fatah, N.H.A.; Amen, Y.; Abdel Bar, F.M.; Halim, A.F.; Saad, H.E.A. (2020). Antioxidants and $\alpha-$ glucosidase inhibitors from Lactuca serriola L. Rec. Nat. Prod. 2020, 14(6), 410-415.

[103] Cağlayan, C.; Taslimi, P.; Demir, Y.; Küçükler, S.; Kandemir, M.F.; Gulcin, I. The effects of zingerone against vancomycin-induced lung, liver, kidney and testis toxicity in rats: The behavior of some metabolic enzymes. J. Biochem. Mol. Toxicol. 2019, 33(10), e22381.

[104] Taslimi, P.; Koksal, E.; Gören, A.C.; Bursal, E.; Aras, A.; Kılıç, O.; Alwasel, S.; Gulcin, I. Anti-Alzheimer, antidiabetic and antioxidant potential of Satureja cuneifolia and analysis of ts phenolic contents by LCMS/MS. Arab. J. Chem. 2020, 13(3), 4528-4537.

[105] Günsel, A.; Bilgiçli, A.T.; Barut, B.; Taslimi, P.; Ozel, A.; Gulcin, I.; Bıyıklıglu, Z.; Yarasir, M.N. Synthesis of water soluble tetra-substituted phthalocyanines: Investigation of DNA cleavage, cytotoxic effects and metabolic enzyme inhibition. J. Mol. Struct. 2020, 214, 128210.

[106] Akıncıoğlu, H.; Gulcin, I. Potent acetylcholinesterase inhibitors: potential drugs for Alzheimer's disease. Mini Rev. Med. Chem. 2020, 20(8), 703-715.

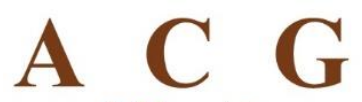

publications

(C) 2021 ACG Publications 